\title{
METHIONINE- AND CHOLINE-DEFICIENT DIET INDUCES HEPATIC CHANGES CHARACTERISTIC OF NON-ALCOHOLIC STEATOHEPATITIS
}

\author{
Éder MARCOLIN ${ }^{1,3}$, Luiz Felipe FORGIARINI², Juliana TIEPPO ${ }^{3}$, Alexandre Simões DIAS ${ }^{3,4}$, \\ Luiz Antonio Rodrigues de FREITAS ${ }^{5}$ and Norma Possa MARRONI ${ }^{6}$
}

\begin{abstract}
Context - Non-alcoholic steatohepatitis is a disease with a high incidence, difficult diagnosis, and as yet no effective treatment. So, the use of experimental models for non-alcoholic steatohepatitis induction and the study of its routes of development have been studied. Objectives - This study was designed to develop an experimental model of non-alcoholic steatohepatitis based on a methionineand choline-deficient diet that is manufactured in Brazil so as to evaluate the liver alterations resulting from the disorder. Methods - Thirty male C57BL6 mice divided in two groups $(\mathrm{n}=15)$ were used: the experimental group fed a methionine- and choline-deficient diet manufactured by Brazilian company PragSoluções ${ }^{\circledR}$, and the control group fed a normal diet, for a period of 2 weeks. The animals were then killed by exsanguination to sample blood for systemic biochemical analyses, and subsequently submitted to laparotomy with total hepatectomy and preparation of the material for histological analysis. The statistical analysis was done using the Student's $t$-test for independent samples, with significance level of 5\%. Results - The mice that received the methionine- and choline-deficient diet showed weight loss and significant increase in hepatic damage enzymes, as well as decreased systemic levels of glycemia, triglycerides, total cholesterol, HDL and VLDL. The diagnosis of non-alcoholic steatohepatitis was performed in $100 \%$ of the mice that were fed the methionine- and choline-deficient diet. All non-alcoholic steatohepatitis animals showed some degree of macrovesicular steatosis, ballooning, and inflammatory process. None of the animals which were fed the control diet presented histological alterations. All nonalcoholic steatohepatitis animals showed significantly increased lipoperoxidation and antioxidant enzyme GSH activity. Conclusion - The low cost and easily accessible methionine- and choline-deficient diet explored in this study is highly effective in inducing steatosis and steatohepatitis in animal model, alterations that are similar to those observed in human livers.
\end{abstract}

HEADINGS - Fatty liver. Methionine. Choline deficiency. Oxidative stress. Mice.

\section{INTRODUCTION}

Non-alcoholic fatty liver disease (NAFLD) is a clinical label used to characterize physiopathological states such as fat accumulation in the liver amounting to $5 \%-10 \%$ of its weight (steatosis), presence of non-alcoholic steatohepatitis (NASH), and even hepatocellular carcinoma due to liver cirrhosis ${ }^{(47)}$. NASH is characterized as fat accumulation in the hepatic tissue associated with various degrees of inflammation and progressive fibrosis ${ }^{(36)}$.

NASH is the third commonest cause of liver disease among ambulatory patients ${ }^{(17,20)}$. In a population-based study conducted between 1997 and 1999 in the city of Porto Alegre (South Brazil), the prevalence of the disease was
$3.18 \%$ in patients with changes at the aminotransferase level ${ }^{(50)}$. These findings may underestimate the real incidence of the disorder, as they include solely those patients who showed biochemical alterations only.

NASH is associated with obesity, diabetes mellitus type II, hyperlipidemia, rapid weight loss in individuals submitted to jejunoileal bypass surgery to treat obesity, and exposure to drugs and industrial toxins ${ }^{(19,23)}$. The recognition of its progressive potential and its high prevalence across the globe are the main reasons why the scientific community is interested in performing studies relating to the disorder ${ }^{(51)}$.

The histological evaluation of liver biopsy is the most refined method to distinguish steatohepatitis from simple steatosis, as well as to define steatosis severity

* Study conducted at the Hospital de Clínicas de Porto Alegre, Porto Alegre, RS, Brasil.

Financial support: This study received financial support in the form of grants from the Coordenação de Aperfeiçoamento de Pessoal de Nivel Superior (CAPES) and from Fundo de Incentivo à Pesquisa e Eventos do Hospital de Clínicas de Porto Alegre (FIPE-HCPA).

Conflict of interest: none.

${ }^{1}$ Post-Graduate Program of Physiology, Universidade Federal do Rio Grande do Sul (UFRGS); ${ }^{2}$ Centro Universitário Metodista, IPA; ${ }^{3}$ Laboratory of Experimental Hepatology and Physiology, Hospital de Clínicas de Porto Alegre - UFRGS; ${ }^{4}$ Program in Rehabilitation and Inclusion, Centro Universitário Metodista, IPA, Porto Alegre, RS, Brasil; ${ }^{5}$ Laboratory of Pathology and Bio-intervention, Fundação Oswaldo Cruz - FIOCRUZ - Salvador, BA, Brasil; ${ }^{6}$ Laboratory of Oxidative Stress and Antioxidants - ULBRA, Canoas, RS, Brasil.

Correspondence: Prof. Norma Possa Marroni - Rua José Kanan Aranha, 102 - Jardim Isabel - 91760-470 - Porto Alegre, RS, Brasil. E-mail: nmarroni@terra.com.br 
and the different grades of inflammation and fibrosis in individuals with $\mathrm{NASH}^{(12)}$. It should be highlighted that few are the prospective studies using serial biopsies to evaluate the progress of the disease in patients with $\mathrm{NASH}^{(5,42)}$.

Concerning treatment for NASH, so far no specific therapy has shown conclusive results and many authors think that patients with steatosis should be only observed and evaluated periodically. Others suggest that gradual weight loss and aerobic physical exercise could benefit obese patients, but further studies are necessary to confirm these hypotheses ${ }^{(22,41,51)}$.

There are few studies on drug treatment in humans ${ }^{(51)}$, and the great difficulty seems to be that the need for performing a second liver biopsy to evaluate treatment effectiveness is the main reason accounting for the small number of such studies, as this is the only truthful way of testing treatment efficacy.

In this sense, the development of experimental models characterizing the physiopathology of NASH, its complications and the use of appropriate treatment can aid in the understanding and explanation of the disease. In experimental studies one can control for genetic heterogeneity, gender differences, environmental factors, and lifestyle, since all animals used in the trials go through similar situations ${ }^{(35)}$.

One determinant for the efficacy of using experimental studies in this disorder concerns the operational costs for each investigation and the time of disease induction. The choice of an experimental model that is effective and in keeping with the need to develop NASH may clarify the actual effect of drug therapy as well as the natural monitoring of the disease.

The use of a diet deficient in essential amino acids such as methionine and choline for inducing non-alcoholic steatohepatitis is a well-accepted model ${ }^{(12)}$. However, the costs and arrangements required to import such food hinder its use in developing countries like Brazil.

Thus, this study was designed to develop an experimental model of NASH using a diet deficient in methionine and choline based on Brazilian-made animal food, and to evaluate the liver alterations arising from the induced disorder.

\section{METHODS}

\section{Animals}

In this trial 30 male C57BL/6 mice were used. They were 8 weeks old and weighed 25 grams in average. They were obtained from the Multidisciplinary Center of Biological Investigation of the University of Campinas (CEMIBUNICAMP), Campinas, SP, Brazil.

The animals were kept in polypropylene cages $(47 \times 34 \times 18 \mathrm{~cm})$, 10 animals in each cage and under standard conditions, with water and food ad libitum and $12 \mathrm{~h}$ light/dark cycle (light cycle from 7 a.m. to 7 p.m.) and controlled temperature $\left(24^{\circ} \mathrm{C} \pm 1.0^{\circ} \mathrm{C}\right)$ and humidity $(55 \% \pm 5 \%)$ in the Animal Experimentation Division of the Hospital de Clínicas of Porto Alegre, RS, Brazil.

\section{Diet composition}

The methionine- and choline-deficient diet (MCD) was manufactured, under our request and guidance, by the
Brazilian company PragSoluções ${ }^{\circledR}$, as described by Newberne and Camargo ${ }^{(40)}$, with modifications.

Two types of rations were manufactured: MCD and control ration, which was identical to MCD but contained the adequate amounts of both amino acids.

\section{Ration characteristics}

The MCD and control rations developed by the Brazilian Co. PragSoluções ${ }^{\circledR}$ Comércio e Serviços Ltda., according to our instructions were provided as $30 \mathrm{~g}$ cubes $(2 \times 2 \mathrm{~cm})$ that must be stored at $2-10^{\circ} \mathrm{C}$ for conservation because of the high content of lipids and saccharose. They are like caramel in color and have good smell and flavor, being well-accepted by the animals as food.

\section{Experimental procedure}

NASH was induced by providing the animals with the MCD ration ad libitum for 2 weeks. The animals in the control group received the same ration, however with the inclusion of methionine and choline in adequate concentrations.

The animals were randomly divided in two groups: control (CO): 15 mice which received the control ration (with the addition of methionine and choline) for 2 weeks; and NASH: 15 mice which received the MCD diet for 2 weeks.

One week prior to the beginning of the study, all animals started receiving the control ration so as to adapt to the new diet.

All experimental procedures were according to the norms established by the Health Research and Ethics Commission by the Research and Postgraduate Group of the Hospital de Clínicas of Porto Alegre (HCPA) (number process 09-050), as described in Guiding principles for research involving animals ${ }^{(49)}$.

\section{Experimental design and animal killing}

On experimental day 1 the animals were randomly assigned to the groups and given their corresponding diets. The animals were weighed and monitored weekly during the experiment.

After 2 weeks the animals were weighed and anesthetized by inhalatory Isoflurane ${ }^{\circledR}$ so that their blood could be sampled from the retro-orbital plexus.

The animals were killed at the end of the experiment by exsanguination under deep anesthesia, followed by cervical dislocation as described in the AVMA guidelines on euthanasia ${ }^{(3)}$. The liver was removed by medium ventral laparotomy with total hepatectomy, a part of which was prepared for the histological analysis and the remaining tissue frozen in liquid nitrogen.

The livers were sectioned and a fraction of their lobes was used for histology, fixed in $10 \%$ formaldehyde solution for $24 \mathrm{~h}$ and included in paraffin blocks for later staining. The remaining tissue was used for biochemical and oxidative stress analysis.

\section{Histological analysis}

For the microscopic analysis, the liver fragments slides were stained with hematoxylin-eosin (H-E) and picrosirius and subsequently assessed by a single pathologist in blind fashion. 
The minimum histological criterion for the diagnosis of NASH was the presence of steatosis associated with hepatocellular ballooning involving zone 3 and lobular inflammatory infiltrate ${ }^{(13)}$. Mallory bodies and sinusoidal fibrosis involving zone 3 could be present or not ${ }^{(28)}$. The grading of both necro-inflammatory activity and fibrosis was according to the classification proposed by Brunt et al. ${ }^{(13)}$. The scoring system used for NASH classification was as recommended by the Pathology Committee of NASH Clinical Research Network $^{(31)}$, semi-quantitatively classifying each case as steatosis (0-3), lobular inflammation (0-2), hepatocellular balloonization (0-2), and fibrosis (0-4).

In the picrosirius red staining, the qualitative analysis was performed using a binocular microscope Nikon Labophot (Tokyo, Japan). The percentage of fibrosis in the liver tissue was determined by a histomorphometric analysis in microscope equipped with a digital camera and connected to an image capturing program (Image-Pro Plus by Media Cybernetics, Bethesda, MD, USA). After analyzing 20 randomized fields per image, the ratios of conjunctive tissue relative to whole liver were calculated, the results appearing in pixels.

\section{Liver integrity analysis}

Liver integrity was assessed by measuring blood levels of enzymes aspartate transaminase (AST), alanine transaminase (ALT) and alkaline phosphatase (ALP).

\section{Biochemical analysis}

The systemic biochemical analyses included glycemia, triglycerides, total cholesterol, high density lipoproteins (HDL), and very low density lipoproteins (VLDL).

\section{Lipoperoxidation analysis}

In the liver homogenate tissues, liver lipoperoxidation was evaluated using the method of thiobarbituric acid reactive substances, which detects the presence of malondialdehyde and other substances from lipid peroxidation of biological material. The results were expressed in micromol per miligram of protein $(\mu \mathrm{mol} / \mathrm{mg} \text { prot })^{(16)}$. The technique consists in heating the homogenate with thiobarbituric acid and the consequent formation of a stained product, measured in spectrophotometer at 535 nanometers $(\mathrm{nm})$.

\section{Antioxidant enzymes analysis}

SOD determination was based on the inhibition of the reaction of superoxide radical with adrenalin. SOD, present in the sample under study, competed for the superoxide radical through the system of detection. The results were expressed as units of SOD per mg of protein ${ }^{(39)}$.

CAT enzyme activity was evaluated by determining, in spectrophotometer, the speed at which peroxide hydrogen $\mathrm{H}_{2} \mathrm{O}_{2}$ $0.3 \mathrm{M}$ ) is broken down (with a wavelength of $240 \mathrm{~nm}$ ). Enzyme activity was expressed in nmol per mg of protein ${ }^{(10)}$.

The activity of enzyme GSH consists in the formation of 2,4 dinitrophenyl-S-glutathione and was measured in spectrophotometer (Varian, Cary model) with wavelength of $340 \mathrm{~nm}$. The results are expressed in $\mu \mathrm{mol} / \mathrm{mg}$ of $\operatorname{protein}^{(9)}$.

\section{Statistical analysis}

The data appear as mean \pm standard error and were statistically submitted to the Student's $t$-test for independent samples, with a level of significance of $5 \%(P<0.05)$.

\section{RESULTS}

\section{Methionine and coline deficient diet}

The diet MCD had good acceptance by the animals. Has a market value $55 \%$ smaller than the imported, with similar efficacy according to findings published in literature ${ }^{(1,2,4,8}$, $14,15,25,32,33,34)$

\section{Morphological and histopathological analyses}

All of the 30 mice submitted to the study completed the 2-week diet period. In the period of this study, do not have lost of animals due MCD diet.

The animals showed good acceptance of the MCD diet and we suggest previously using the control ration in the 1 st week so that they can adapt to the new diet. The rodents were carefully observed because, owing to its less hard consistence, the MCD diet could induce overgrowth of the animals' fangs due to diminished attrition of the dentin ${ }^{(18)}$.

As shown in Table 1 and Figure 1, the animals' body weight in the NASH group was, in average, $6.93 \pm 0.18 \mathrm{~g}$ lower than in the control group on the last day of the study, but such

TABLE 1. Morphological evaluation and biochemical tests

\begin{tabular}{lcc}
\hline & Control & NASH \\
\hline Body weight $(\mathrm{g})$ & $26.69 \pm 0.51$ & $19.76 \pm 0.69$ \\
Hepato somatic index (\%) & $4.66 \pm 0.12$ & $3.59 \pm 0.33$ \\
Aspartate transaminase (AST) & $110.60 \pm 16.96$ & $449.00 \pm 41.52^{*}$ \\
Alanine transaminase (ALT) & $62.13 \pm 7.29$ & $435.95 \pm 36.44^{*}$ \\
Alkaline phosphatase (ALP) & $93.38 \pm 2.87$ & $106.19 \pm 2.71^{*}$ \\
Glycemia & $220.75 \pm 15.52$ & $74.24 \pm 6.17 *$ \\
Triglycerides & $124.6 \pm 15.41$ & $63.75 \pm 2.13^{*}$ \\
Total cholesterol & $122.91 \pm 5.93$ & $57.33 \pm 2.49 *$ \\
HDL & $114.86 \pm 6.81$ & $52.87 \pm 2.06 *$ \\
VLDL & $27.3 \pm 3.35$ & $12.75 \pm 0.43^{*}$ \\
\hline
\end{tabular}

*Statistically significant difference between the groups for Student's t-test for independent samples; $P<0.05 ; \mathrm{n}=15$

$\mathrm{NASH}=$ non-alcoholic steatohepatitis.

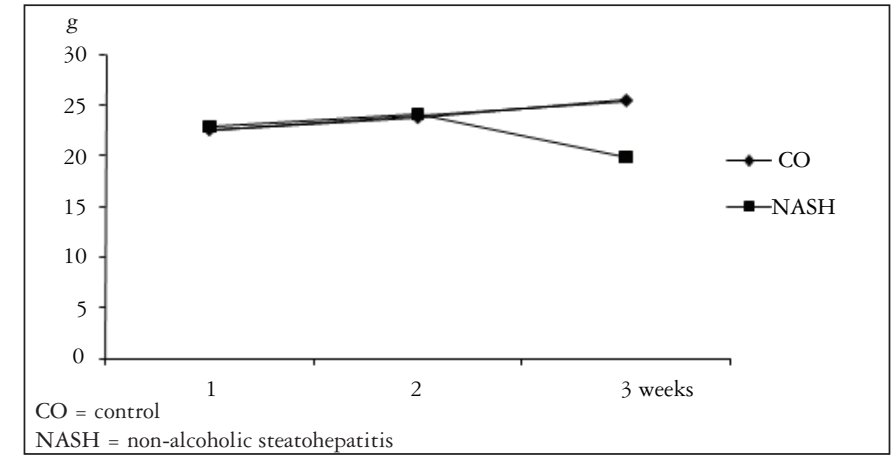

FIGURE 1. Variation in animal weight in 2 weeks $(\mathrm{g})$ 
difference was not significant. The same was observed in the hepato-somatic index.

Concerning histological findings, no animal receiving the $\mathrm{CO}$ ration presented histological alterations, all being considered with normal livers (Figures $2 \mathrm{~A}$ and $2 \mathrm{~B}$ ).

Of the animals in the NASH group with the MCD diet (Table 2), all had microvesicular steatosis, macrovesicular steatosis above grade 1 , and hepatocellular ballooning. The inflammatory process showed mean grade of $2.22 \pm 0.26$ in the NASH group. The diagnosis of non-alcoholic steatohepatitis was made in all of the animals of the NASH group (Figures $3 \mathrm{~A}$ and $3 \mathrm{~B})$.

The degree of fibrosis as analyzed by picrosirius staining showed small quantity of fibrosis without statistical difference between the CO and NASH groups (18.26 \pm 0.33 e $18.64 \pm$ 0.59 pixels).

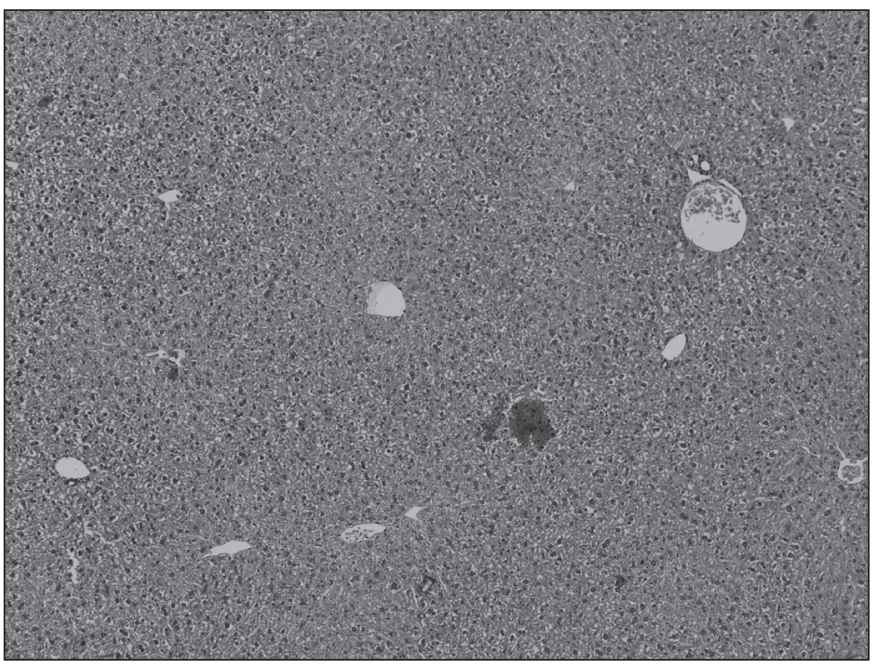

FIGURE 2A. Photomicrograph of liver in control animal. (H-E, 100x)

\section{Biochemical and liver integrity analyses}

The plasma levels of liver enzymes AST, ALT and FA were elevated with a statistically significant difference for the animals in the NASH group

The plasma levels of glycemia, triglycerides, total cholesterol, HDL and VLDL were reduced in the NASH as compared to the $\mathrm{CO}$ group, with statistically significant difference (Table 1 ).

\section{Lipoperoxidation and liver antioxidant enzymes analysis}

Thiobarbituric acid reactive substances results showed that the livers of animals in the NASH group had increased levels of lipoperoxidation as compared to CO animals (Table 3 ).

Superoxide dismutase and catalase activity of enzymes did not show any statistically significant differences across the groups, but total glutathione activity was significantly increased in the NASH group (Table 3).

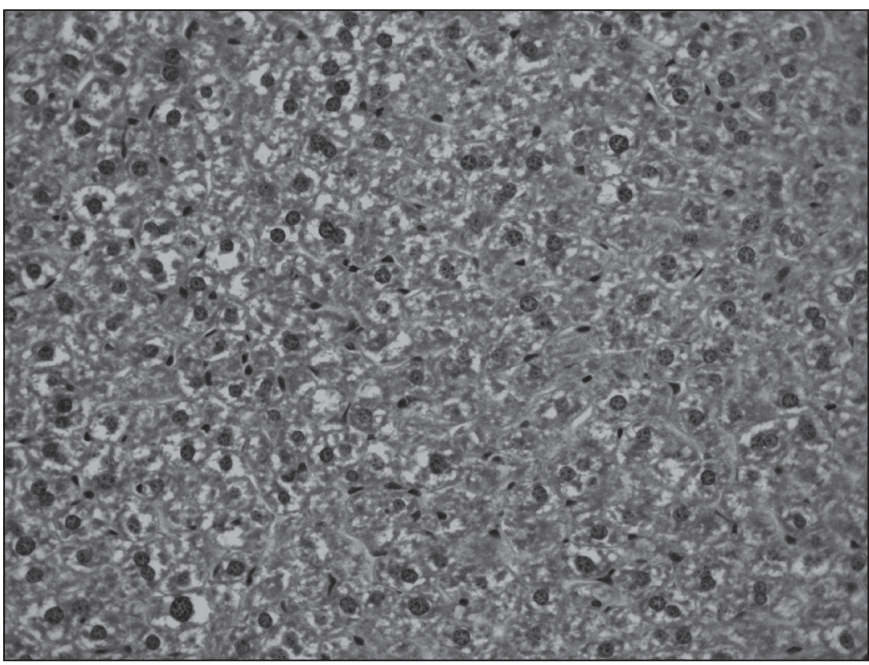

FIGURE 2B. Photomicrograph of liver in control animal. (H-E 400x).

TABLE 2. Scores in the histopathological analyses

\begin{tabular}{|c|c|c|c|c|}
\hline Item & Definition & Score/Code & Control $(n=5)$ & NASH $(n=10)$ \\
\hline \multirow[t]{4}{*}{ Steatosis } & $<5 \%$ & 0 & 0 & $1.44 \pm 0.229 *$ \\
\hline & $5 \%-33 \%$ & 1 & & \\
\hline & $>33 \%-66 \%$ & 2 & & \\
\hline & $>66 \%$ & 3 & & \\
\hline \multirow[t]{2}{*}{ Microvesicular steatosis } & Not Present & 0 & 0 & $0.67 \pm 0.211 *$ \\
\hline & Present & 1 & & \\
\hline \multirow[t]{4}{*}{ Inflammation } & None & 0 & 0 & $2.22 \pm 0.263 *$ \\
\hline & $<2$ foci per $200 x$ field & 1 & & \\
\hline & $2-4$ foci per $200 x$ field & 2 & & \\
\hline & $>4$ foci per $200 x$ field & 3 & & \\
\hline \multirow[t]{3}{*}{ Ballooning } & None & 0 & 0 & $1.44 \pm 0.229 *$ \\
\hline & Few balloon cells & 1 & & \\
\hline & Many cells prominent ballooning & 2 & & \\
\hline
\end{tabular}

*Statistically significant difference between the groups for Mann-Whitney test for independent samples; $\mathrm{P}<0.05$ NASH = non-alcoholic steatohepatitis 


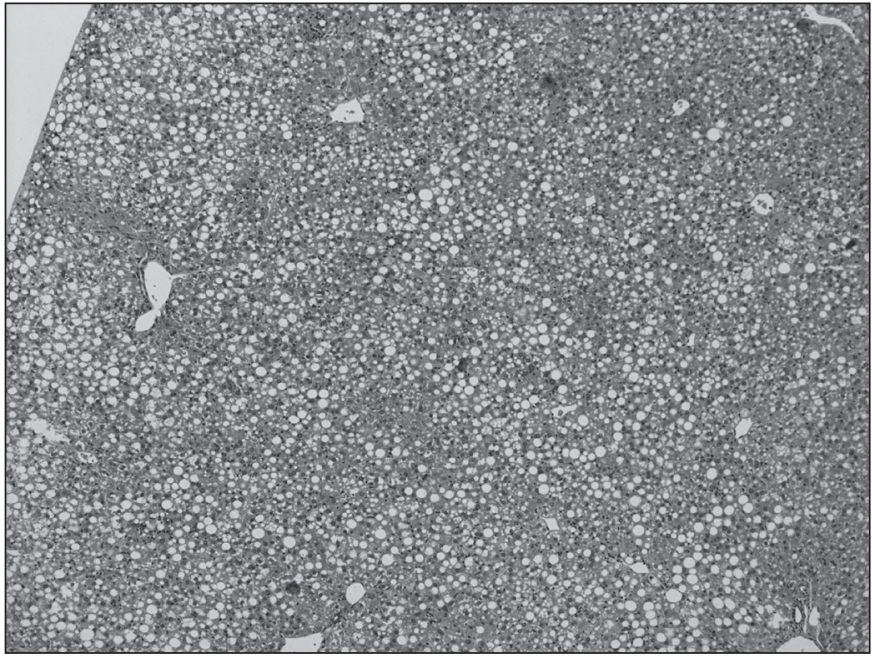

FIGURE 3A. Photomicrograph of liver in NASH animal showing macrovesicular steatosis and inflammatory activity (H-E 100x)

TABLE 3. Lipoperoxidation and antioxidant enzymes activity in liver

\begin{tabular}{lcc}
\hline & Control & NASH \\
\hline TBARS $(\mu \mathrm{mol} / \mathrm{mg}$ of protein) & $0.97 \pm 0.06$ & $3.02 \pm 0.22 *$ \\
SOD $(1 \mathrm{U}$ SOD$/ \mathrm{mg}$ of protein) & $15.48 \pm 2.47$ & $21.64 \pm 1.68$ \\
CAT $(\mathrm{pmol} / \mathrm{mg}$ of protein) & $2.15 \pm 0.58$ & $2.37 \pm 0.41$ \\
Total GSH $(\mu \mathrm{mol} / \mathrm{mg}$ of protein) & $0.02 \pm 0.01$ & $0.13 \pm 0.03 *$ \\
\hline
\end{tabular}

*Statistically significant difference between the groups for Student's $t$-test for independent samples;

$P<0.05 ; \mathrm{n}=15 \mathrm{NASH}=$ non-alcoholic steatohepatitis

\section{DISCUSSION}

The experimental diets facilitate the routine of researchers because they allow a fast delivery of results with the implementation of diseases for their studies. Because it allows a better understanding of the physiopathology and helps to clarify the mechanisms involved in the transition from steatosis to NASH so as to test the effectiveness of various available drugs for treatment ${ }^{(51)}$, the use of experimental models of $\mathrm{NASH}$ is of paramount importance.

The induction of NASH has been historically performed variously: by drug induction ${ }^{(8,30,43)}$ : tetracycline, amiodarone, corticosteroids, etc; with the use of genetically obese rats or with genetic manipulation; and with the use of diets that promote its occurrence, either because they are high in fat or low in amino acids ${ }^{(43,48)}$.

The use of the MCD diet is considered as the main model used for studying $\mathrm{NASH}^{(35)}$. The diets deficient in methionine and choline are marketed in the form of pellets or cubes. They are mostly imported from first world countries such as the United States, something that makes research more difficult, time-consuming, and expensive. With the development of this Brazilian product, not only the costs were reduced by $45 \%$ but also the delivery time was significantly reduced as there were no customs procedures and related difficulties to go through.

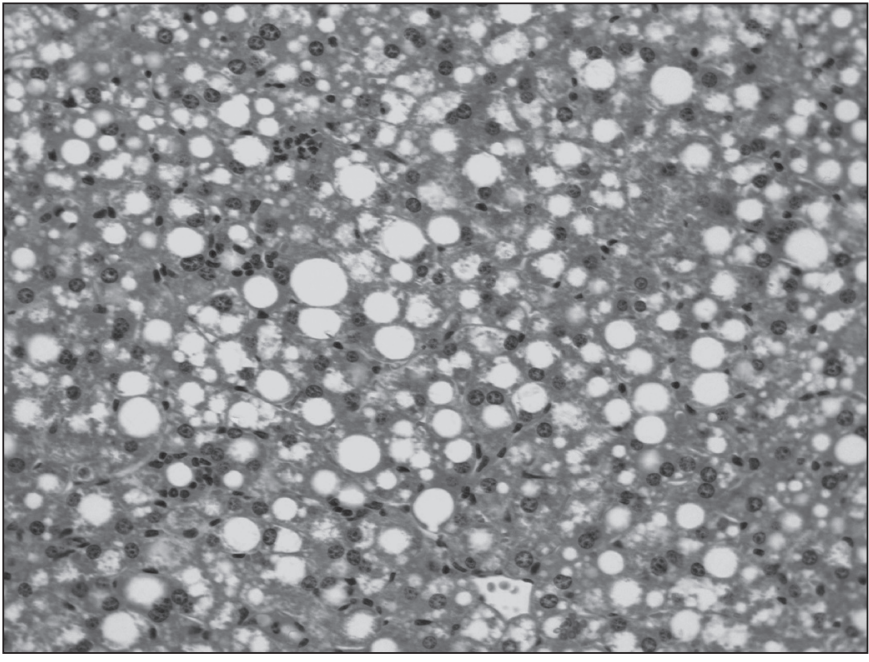

FIGURE 3B. Photomicrograph of liver in NASH animal showing macrovesicular steatosis, ballooning and inflammatory activity. (H-E 400x)

The first characterization of steatohepatitis was the one developed by continual and excessive consumption of alcohol. Experimental and epidemiological studies have shown that chronic ingestion of ethanol causes depletion of such nutrients as choline, folate, and methionine due to the toxic interaction of alcohol with their metabolism ${ }^{(7,45)}$. Accordingly, diets lacking methionine and choline were developed as a model of NASH induction in rodents producing the main characteristics of non-alcoholic steatohepatitis in humans ${ }^{(29)}$.

While the MCD diet is rich in saccharose $(40 \%)$ and fat $(10 \%)$, it lacks two crucial components, methionine and choline $^{(35)}$, the main precursors of NASH in this model. Choline is an essential amine that is part of the vitamin B complex. It is present in the cell membrane lipids and in the neurotransmitter acetylcholine. The recommended daily ingestion of choline is $425-550 \mathrm{mg}$ for adults, and its sources include yolk, beans, soy and the like, soy lecithin, among others ${ }^{(53)}$.

Choline is necessary for the synthesis of phospholipids of the cell membrane, methyl metabolism, cholinergic neurotransmission, transmembrane signaling, and transport and metabolism of lipid cholesterol ${ }^{(54)}$.

The debate concerning the use of choline in the human diet centers around the metabolism of phosphatidyl-choline by phospholipases or de novo synthesis of choline ${ }^{(44)}$. In the liver, biosynthesis of the choline portion occurs through methylation of phosphatidylethanolamine using S-adenosylmethionine as methyl donor ${ }^{(11)}$.

This ability of de novo synthesis of choline means that the demand for choline can be partly met by methylic groups derived from carbon metabolism (via methyl folate and methionine). Due to this inter-relation of choline, methionine, folic acid, and B6 and B12 vitamins, it is believed that, even if nutrients are available in high enough quantities to sustain normal growth and function, the rates of de novo synthesis 
of choline are not sufficient to meet the essential demand of choline $e^{(53)}$.

The accumulation of fat in the liver resulting from choline deficiency occurs because choline is required to make the phosphatidyl-choline portion in VLDL (very low density lipoprotein) particles ${ }^{(24,46)}$. In the absence of choline, VLDL is not secreted and triacylglycerol (triglyceride) builds up in the liver cytosol. These quotes are in agreement with our data, where the plasma levels of triglycerides and cholesterol, in particular VLDL, are low (Table 1), but lipid accumulation in the liver is extensive (Figure 3A).

Rodents deficient in choline showed increased lipoperoxidation in liver ${ }^{(6)}$. Nuclear lipid peroxidation, as a great source of free radicals, is pointed as a DNA damager and inducer of carcinogenesis, along with dysfunction of programmed cell death (apoptosis) ${ }^{(52)}$. In our experiments we found a significant increase in liver lipoperoxidation in the animals with NASH induced by two-week MCD diet.

The other component that is scarce in the MCD diet, methionine, is an essential amino acid that is converted to S-adenosylmethionine and used by methyl transferases which aggregate the methyl group to the DNA, RNA, proteins, and lipids and form S-adenosylhomocysteine that is hydrolized to homocysteine ${ }^{(38)}$.

When methionine is present in excess, glycin $\mathrm{n}$-methyltransferase and cystathione- $\mathrm{B}$-synthase are activated by important regulatory pathways, using excess $-\mathrm{CH}_{3}$ to convert glycin to n-methyl glycin and, then, condense homocysteine with serin to form cystathionin, which is cleaved by gamma cystathionases forming cysteine and $\alpha$-ketobutirate. When methionine is low, the activities of both regulatory enzymes are decreased as homocysteine begins to be recycled to methionine, through methionine-synthase dependent cobalamin, which simultaneously converts - $\mathrm{CH}_{3}-$ tetrahydrofolate to tetrahydrofolate ${ }^{(26)}$.

Cysteine, formed by methionine, is the limiting reagent for glutathione (GSH) synthesis, the main cellular antioxidant. Therefore, two major homeostatic systems are interlinked and coordinately regulated by methionine metabolism, cellular methylation and the redox buffer system ${ }^{(38)}$. As shown in our results, antioxidant enzymes SOD and CAT in the NASH group, which should be elevated as they detoxify the excess reactive oxygen species shown by lipoperoxidation, were not any different from the control group, showing the depletion of the scavenging ability of these enzymes. As this is about a 2 -week model, we think the redox system is being maintained by GSH which, at this time, is still elevated in the NASH group (Table 3), as it is the last resource to fight off reactive oxygen species.

Deficiency of methionine and the other lipotropic factors (folate, B12, choline) are predictive of liver steatosis. Moreover, there is decreased formation of S-adenosylmethionine with decreased activation of folate, tRNA, creatine synthesis, lecithin, and norepinephrine ${ }^{(37)}$.

Animals fed this diet (MCD) have significant loss of body weight (about $40 \%$ of baseline weight in 10 weeks) $)^{(48)}$. The NASH animals in our experiment had a $25.96 \%$ decrease in their body weights in two weeks of treatment. Although the liver decreases in size, the liver/body weight ratio is unchanged ${ }^{27}$, ${ }^{33,48)}$. This is in agreement with our findings.

The animals develop severe steatosis particularly in zone 3 (pericentral) and subsequent development of necroinflammation (especially in lymphocytes and polimorphonuclear neutrophils), and steatohepatitis in rodents fed the MCD diet leads to progressive fibrosis ${ }^{(27,33,48)}$. These reports are similar to the results obtained in our model (Figures $3 \mathrm{~A}$ and $3 \mathrm{~B}$ ).

The MCD diet is extremely effective as an experimental model for the development and study of NASH. Studied since the mid $1940 \mathrm{~s}^{(21)}$, this diet has been refined and used for inducing a form of NASH that is very similar to the human one, with implications of oxidative stress, elevated levels of $\mathrm{TNF} \alpha$, and increased lipid levels ${ }^{(3))}$.

The present study demonstrated that the use of a methionineand choline-deficient diet manufactured nationally is efficacious, cost-effective, easy to purchase (as there is no need to import it) and, especially, it does develop the characteristics of a form of NASH that is similar to the human one in only two weeks. Thus, the use of this experimental model is suggested for the study of this disorder and new potential forms of treatment.

\section{ACKNOWLEDGEMENTS}

We thank the Research Incentive Fund of Hospital de Clínicas de Porto Alegre (HCPA) and the staff at Laboratory of Experimental Hepatology and Physiology of HCPA for their excellent scientific support. Student doctor Éder Marcolin, Dr. Alexandre Simões Dias and Dr. Juliana Tieppo were thanking Research Incentive supported by grants from the Brazilian agencies Coordenação de Aperfeiçoamento de Pessoal de Nível Superior (CAPES). And special thanks for the Fundação Oswaldo Cruz - Bahia (FIOCRUZ). 
Marcolin E, Forgiarini LF, Tieppo J, Dias AS, Freitas LAR, Marroni NP. Dieta deficiente em metionina e colina induz mudanças hepáticas características de esteatohepatite não-alcoólica. Arq Gastroenterol. 2011;48(1):72-9.

RESUMO - Contexto - A esteatohepatite não-alcoólica é uma doença com alta incidência, difícil diagnóstico e tratamentos ainda não efetivos. Com isso, o uso de modelos experimentais para indução da esteatohepatite não-alcoólica e o estudo das rotas de desenvolvimento desta doença vem sendo empregado. Objetivo - Desenvolver um modelo experimental de esteatohepatite não-alcoólica a partir do uso de uma dieta deficiente de metionina e colina fabricada no Brasil e avaliar as alterações hepáticas decorrentes da doença. Métodos - Foram utilizados 30 camundongos machos da linhagem C57BL6, onde a metade foi alimentada com dieta deficiente em metionina e colina desenvolvida no Brasil e o restante com dieta controle no período de duas semanas. Após, os animais foram mortos por exaguinação e foi realizada laparotomia com hepatectomia total e preparo do material para análise histológica, coleta de sangue para análises bioquímicas sistêmicas. O nível de significância foi 5\%. Resultados - Os ratos que receberam a dieta deficiente em metionina e colina apresentaram perda de peso e aumento significativo das enzimas de integridade hepática e diminuição dos níveis bioquímicos sistêmicos de glicemia, triglicerídeos, colesterol total, HDL e VLDL. Todos os animais com esteatohepatite não-alcoólica mostraram, pelo menos, algum grau de esteatose macrovesicular. O diagnóstico de esteatohepatite não-alcoólica foi realizado em $100 \%$ dos camundongos que receberam a dieta deficiente em metionina e colina e nenhum dos animais que recebeu dieta controle apresentou alterações histológicas. Os animais com esteatohepatite não-alcoólica apresentaram aumento de lipoperoxidação e da enzima antioxidante GSH. Conclusão - A dieta deficiente de metionina e colina desenvolvida neste estudo apresenta índices elevados de indução de esteatose e esteatohepatite em modelo animal, apresentando comportamento patológico semelhante ao humano, com custo adequado e facilidade na sua aquisição.

DESCRITORES - Fígado gorduroso. Metionina. Deficiência de colina. Estresse oxidativo. Camundongos.

\section{REFERENCES}

1. Albright CD, Liu R, Bethea TC, Da Costa KA, Salganik RI, Zeisel SH. Choline deficiency induces apoptosis in SV40-immortalized CWSV-1 rat hepatocytes in culture. Faseb J. 1996;10:510-6.

2. Albright CD, Zeisel SH, Salganik RI. Choline deficiency induces apoptosis and decreases the number of eosinophilic preneoplastic foci in the liver of OXYS rats. Pathobiology. 1998;66:71-6.

3. American Veterinary Medical Association - AVMA. AVMA guidelines on euthanasia (Formerly Report of the AVMA Panel on Euthanasia) [Internet]. Schaumburg, IL, 2007. Available from: http://www.avma.org/issues/animal_welfare/ euthanasia.pdf

4. Ames BN. DNA damage from micronutrient deficiencies is likely to be a major cause of cancer. Mutat Res. 2001;475:7-20.

5. Bacon BR, Farahvash MJ, Janney CG, Neuschwander-Tetri BA. Nonalcoholic steatohepatitis: an explanded clinical entity. Gastroenterology. 1994; 107:1103-9.

6. Banni S, Corongiu FP, Dessi MA, Iannone A, Lombardi B, Tomasi A, Vannini V. Free radicals and lipid peroxidation in liver of rats kept on a diet devoid of choline. Free Radic Res Commun. 1989;7:233-40.

7. Barak AJ, Beckenhauer HC. The influence of ethanol on hepatic transmethylation. Alcohol Alcohol. 1988;23:73-7.

8. Berson A, De Beco V, Letteron P, Robin MA, Moreau C, El Kahwaji J, Verthier N, Feldmann G, Fromenty B, Pessayre D. Steatohepatitis-inducing drugs cause mitochondrial dysfunction and lipid peroxidation in rat hepatocytes. Gastroenterology. 1998;114:764-74.

9. Beutler E, Duron O, Kelly BM. Improved method for determination of blood glutathione. J Lab Clin Med. 1963;61:882-8.

10. Boveris A, Chance B. The mitochondrial generation of hydrogen peroxide: general propertiesand effect of hyperbaric oxygen. Biochem J. 1973;134:707-16.

11. Bremer J, Greenberg DM. Biosynthesis of choline in vitro. Biochim Biophys Acta. 1960;37:173-5.

12. Brunt E. Pathology of nonalcoholic steatohepatitis. Hepatol Res. 2005;33: 68-71.

13. Brunt EM, Janney CG, Di Bisceglie AM, Neuschwander-Tetri BA, Bacon BR Nonalcoholic steatohepatitis: a proposal for grading and staging the histological lesions. Am J Gastroenterol. 1999;94:2467-74.

14. Brunt EM. Pathology of nonalcoholic steatohepatitis. Hepatol Res. 2005;33: 68-71.

15. Brunt EM, Tiniakos DG. Pathological features of NASH. Front Biosci. 2005;10:1475-84.

16. Buege J, Aust S. Microssomal lipid peroxidation. Methods Enzimol. 1978:52:302-10.

17. Caldwell SH, Oelsner DH, Iezzoni JC, Hepenheide EE, Battle EH, Driscoll CJ Cryptogenic cirrhosis: clinical characterization and risk factors for underlying disease. Hepatology. 1999;29:664-9.
18. Carleton MD, Musser GG. Order Rodentia. In: Wilson DE, Reeder DM, editors. Mammal species of the world: a taxonomic and geographic reference. 3rd ed. Baltimore: Johns Hopkins University Press; 2005. v.2, p.745-52.

19. Chitturi S, Farrel GC. Etiopathogenesis of nonalcoholic steatohepatitis. Semin Liver Dis. 2001;21:27-41

20. Clark JM, Brancati FL, Diehl AM. Nonalcoholic fatty liver disease. Gastroenterology. 2002;122:1649-57.

21. Engel RW, Salmon WD. Improved diets for nutritional and pathologic studies of choline deficiency in rats. J Nutr. 1941;22:109-21.

22. Eriksson S, Eriksson KF, Bondesson L. Nonalcoholic steatohepatitis in obesity: a reversible condition. Acta Med Scand. 1986;220:83-8.

23. Farrel GC. Drugs and steatohepatitis. Semin Liver Dis. 2002;22:185-94.

24. Fast DG, Vance DE. Nascent VLDL phospholipid composition is altered when phosphatidylcholine biosynthesis is inhibited: evidence for a novel mechanism that regulates VLDL secretion. Biochim Biophys Acta. 1995;1258:159-68.

25. Freitas L, Cotrim H. Atlas histológico de esteato-hepatite não alcoólica - NASH Salvador: Zambon; 2006

26. Frontiera MS, Stabler SP, Kolhousea JF, Allen RH. Regulation of methionine metabolism: effects of nitrous oxide and excess dietary methionine. J Nutrion Biochem. 1993;5:28-38

27. George J, Pera N, Phung N, Leclercq I, Yun Hou J, Farrell G. Lipid peroxidation, stellate cell activation and hepatic fibrogenesis in a rat model of chronic steatohepatitis. J Hepatol. 2003;39:756-64

28. Harrison S, Neuschwander-Tetri B. Nonalcoholic fatty liver disease and nonalcoholic steatohepatitis. Clin Liver Dis. 2004;8:861-79.

29. Ip E, Farrell GC, Robertson G, Hall P, Kirsch R, Leclercq I. Central role of PPARalpha-dependent hepatic lipid turnover in dietary steatohepatitis in mice. Hepatology. 2003;38:123-32.

30. Kakuma T, Lee Y, Higa M, Wang Z, Pan W, Shimomura I, Unger RH. Leptin, troglitazone, and the expression of sterol regulatory element binding proteins in liver and pancreatic islets. Proc Natl Acad Sci U S A. 2000;97:8536-41.

31. Kleiner DE, Brunt EM, Van Natta M, Behling C, Contos MJ, Cummings OW, Ferrell LD, Liu YC, Torbenson MS, Unalp-Arida A, Yeh M, McCullough AJ, Sanyal AJ; Nonalcoholic Steatohepatitis Clinical Research Network. Design and validation of a histological scoring system for nonalcoholic fatty liver disease. Hepatology. 2005;41:1313-21.

32. Koteish A. Diehl A. Animal models of steatosis. Semin Liver Dis. 2001:21:89-104

33. Leclercq IA, Farrell GC, Field J, Bell DR, Gonzalez FJ, Robertson GR. CYP2E1 and CYP4A as microsomal catalysts of lipid peroxides in murine nonalcoholic steatohepatitis. J Clin Invest. 2000;105:1067-75.

34. Leclercq IA. Pathogenesis of steatohepatitis: insights from the study of animal models. Acta Gastroenterol Belg. 2007;70:25-31.

35. London RM, George J. Pathogenesis of NASH: animal models. Clin Liver Dis. 2007;11:55-74.

36. Ludwing J, Viggiano T, McGill D, Oh B. Non-alcoholic steatohepatitis. Mayo Clinic Proc. 1980;55:434-8 
37. Maio R, Dichi JB, Burini RC. Implicações do alcoolismo e da doença hepática crônica sobre o metabolismo de micronutrientes. Arq Gastroenterol. 2000;37:120-4.

38. Martinov MV, Vitvitsky VM, Banerjee R, Ataullakhanov FI. The logic of the hepatic methionine metabolic cycle. Biochim Biophys Acta. 2010;1804:89-96.

39. Misra HP, Fridovich I. The role of superoxide anion in the autoxidation of epinephrine and a simple assay for superoxide dismutase. J Biol Chem. 1972;247:3170-5.

40. Newberne PM, Camargo JLVD, Clark AJ. Choline deficiency, partial hepatectomy and liver tumors in rats and mice. Toxic Pathol. 1982;10:95-106.

41. Palmer M, Schaffener F. Effect of weight reduction on hepatic abnormalities in overweight patients. Gastroenterology. 1990;99:1408-13.

42. Powell EE, Cooksley WG, Hanson R, Searle J, Halliday JW, Powell LW. The natural history of nonalcoholic steatohepatitis: a follow-up study of forty-two patients for up to 21 years. Hepatology. 1990;11:74-80.

43. Rogers A, Newberne P. Alcoholic and nutritional fatty liver and cirrhosis. Am J Pathol 1973;73:817-20.

44. Schann BD. O papel da proteína quinase $\mathrm{C}$ no desenvolvimento das complicações vasculares do diabetes mellitus. Arq Bras Endocrinol Metab. 2003;47:654-62.

45. Trimble KC, Molloy AM, Scott JM, Weir DG. The effect of ethanol on onecarbon metabolism: increased methionine catabolism and lipotrope methyl-group wastage. Hepatology. 1993;18:984-9.

46. Vance JE. Secretion of VLDL, but not HDL, by rat hepatocytes is inhibited by the ethanolamine analogue N-monomethylethanolamine. J Lipid Res. 1991;32:1971-82.
47. Varela-Rey M, Embade N, Ariz U, Lu SC, Mato JM, Martínez-Chantar ML. Non-alcoholic steatohepatitis and animal models: understanding the human disease. Int J Bichem Cell Biol. 2009;41:969-76.

48. Weltman MD, Farrell GC, Liddle C. Increased hepatocyte CYP2E1 expression in a rat nutritional model of hepatic steatosis with inflammation. Gastroenterology. 1996;111:1645-53.

49. World Medical Association; American Physiological Society. Guiding principles for research involving animals and human beings. Am J Physiol Regul Integr Comp Physiol. 2002;283:R281-3.

50. Zamin I Jr, Mattos AA, Zettler CG. Non-alcoholic steatohepatitis in nondiabetic obese patients. Can J Gastroenterol. 2002;16:303-7.

51. Zamin I Jr, Mattos AA, Mattos AZ, Migon E, Soares E, Perry ML. Modelo experimental de esteatohepatite não-alcoólica com dieta deficiente em metionina e colina. Arq Gastroenterol. 2009;46:69-74

52. Zeisel SH, Albright CD, Shin OH, Mar MH, Salganik RI, da Costa KA. Choline deficiency selects for resistance to $\mathrm{p} 53$-independent apoptosis and causes tumorigenic transformation of rat hepatocytes. Carcinogenesis. 1997;18:731-8.

53. Zeisel SH. Choline: an essential nutrient for humans. Nutrition. 2000;16:66971.

54. Zeisel SH, da Costa KA. Choline: an essential nutrient for public health. Nutr Rev. 2009;67:615-23.

Received 28/5/2010 Accepted 2/8/2010 